\title{
Asymptomatic Bacteriuria or Urinary Tract Infection? New and Old Biomarkers
}

\author{
Francesca K Martino $^{1, *(D)}$ and Giacomo Novara ${ }^{2}$ (D) \\ 1 UO Nephrology, Dialysis and Kidney Transplant, San Bortolo Hospital, 36100 Vicenza, Italy \\ 2 Department of Surgery, Oncology and Gastroenterology, Urology Clinic University of Padua, 35100 Padua, Italy; \\ giacomonovara@gmail.com \\ * Correspondence: francesca.martino.k@gmail.com; Tel.: +39-0444-753650; Fax: +39-0444-753973
}

Citation: Martino, F.K.; Novara, G. Asymptomatic Bacteriuria or Urinary Tract Infection? New and Old Biomarkers. Int. J. Transl. Med. 2022, 2,52-65. https://doi.org/10.3390/ ijtm2010006

Academic Editor: François Fenaille

Received: 3 December 2021

Accepted: 25 January 2022

Published: 1 February 2022

Publisher's Note: MDPI stays neutral with regard to jurisdictional claims in published maps and institutional affiliations.

Copyright: (c) 2022 by the authors Licensee MDPI, Basel, Switzerland. This article is an open access article distributed under the terms and conditions of the Creative Commons Attribution (CC BY) license (https:/ / creativecommons.org/licenses/by/ $4.0 /)$.

\begin{abstract}
Urinary tract infections (UTIs) are among the most common infective disease in the adult population. UTI diagnosis is based essentially on the presence of lower urinary tract symptoms (e.g., dysuria, urgency, and frequency) and the evidence of bacteriuria (by dipstick testing and/or urine culture). UTI diagnosis is not always easy because symptoms can be vague, or patient basal conditions can interfere negatively with the diagnostic process, whereas urine culture is still ongoing. In those cases, the differential diagnosis among UTIs and asymptomatic bacteriuria (ABU) may be challenging, while the clinician has to decide whether to start an antibiotic treatment shortly. The purpose of the present review is to analyze the biomarkers that could help in UTI diagnosis. Some biomarkers, such as procalcitonin, interleukin-6, neutrophil gelatinase-associated lipocalin, chemokines, lactoferrin, and bone morphogenetic protein-2, seem promising in UTI diagnosis, while other biomarkers failed to show any utility. Whereas a single biomarker was not enough, a combination of biomarkers could have more chances to help in the diagnosis.
\end{abstract}

Keywords: urinary tract infections; asymptomatic bacteriuria; biomarker

\section{Introduction}

Urinary tract infections (UTIs) are among the most common infections in the adult population [1]. In non-pregnant healthy women, the diagnosis of UTI is straightforward, based on urinary symptoms, such as dysuria, frequency, and urgency in the absence of vaginal discharge [2]. In such patients, urine culture is not recommended to diagnosticate UTI, not improving the diagnosis accuracy of the clinical assessment [3]. In other cases, including recurrent UTIs (more than two episodes in the last six months or more than three UTIs in one year), male gender, pregnant women, patients with relevant anatomical/functional abnormalities of the urinary tract, immunocompromised patients, indwelling urinary catheters, renal diseases, and diabetes mellitus, the urine culture has a pivotal role in the diagnosis of UTIs [2]. Therefore, in cases such as complicated UTIs and recurrent UTIs, the presence of urinary symptoms and the detection of a pathogen by urine culture impact antibiotic treatment. In co-morbid patients and the elderly, UTI symptoms could be atypical or related to other conditions. For example, in patients with a cognitive impairment, it is not easy to determine the presence of lower urinary tract symptoms (LUTS), whereas in those patients with prostatic enlargement, non-infectious urethritis, bladder dysfunction, bladder tumors, and distal ureteric stone, LUTS could be present without concomitant UTIs. Finally, the results of urine cultures are not immediately available and could take 1-3 days. In this scenario, the diagnosis and the related antibiotic treatment can be a challenge. An inappropriate antibiotic therapy increases the risk of antibiotic resistance [4], and it is a financial burden for the community [5]. Conversely, a delay of an appropriate treatment could impact patient conditions, considering that mortality rates due to urosepsis can be as high as $16 \%$ [6]. Consequently, there is a strong need for biomarkers able to ease the clinical diagnosis of UTIs. The purpose of the present review is to assess the role of biomarkers in 
the diagnosis of UTIs. Specifically, we focus on the uncertain diagnosis when the symptoms are vague or difficult to interpret, evaluating the biomarkers that can help to discriminate between asymptomatic bacteriuria and UTIs.

\section{Search Strategy}

We performed a non-systematic literature search using the following strategy on Pubmed and Scopus in September 2021. Specifically, we searched for the terms "Urinary tract infection" and "biomarker" in the Pubmed Mesh Resources. Moreover, we performed a free text search in Pubmed and Scopus adopting the following search terms: "Procalcitonin", "Interleukin 6", "Neutrophil Gelatinase associated Lipocalin", "Proadenomedullin", "adenosine-5-triphosphate", "Tamm-Horsfall protein", "Bone morphogenetic protein-2", "beta2-Microglobulin", and "lactoferrin". Finally, we restricted our results by adopting the following limits: "English" language and "adults". We screened all the abstracts to identify all the relevant studies. Appendix A shows the details for every biomarker term.

\section{Results and Discussion}

\subsection{Procalcitonin}

Procalcitonin (PCT) is a precursor of the hormone calcitonin and belongs to acute phase reactants. In inflammatory conditions, PCT levels increase significantly. Specifically, PCT increases during bacterial infections and seems to provide supplemental information in the diagnosis of some bacterial infections, such as respiratory tract infection and urosepsis [7]. Furthermore, PCT levels correlate to bacterial load, and consequentially its levels decrease with the improvement in clinical conditions. Such peculiarities provide prognostic information in patients with infections, suggesting the management of bacterial infection, especially in septic disease [7]. On the other hand, two recent meta-analyses in children disputed this promising ability in UTI diagnosis, showing little accuracy for cystitis (AUC around 0.71 in ROC curve) [8,9], and limited evidence supports its utility in pyelonephritis diagnosis [10]. Consequently, PCT could not be recommended in clinical practice as a predictive marker of cystitis or pyelonephritis in children.

Table 1 summarizes the characteristics and the main results of the five studies evaluating the role of PCT in the diagnosis of UTIs.

Table 1. Procalcitonin diagnostic value in UTIs, in a target population of adults.

\begin{tabular}{|c|c|c|c|c|c|}
\hline $\begin{array}{c}\text { Study } \\
\text { Reference }\end{array}$ & Type of Study & Type of Patients & $\begin{array}{c}\text { Number of } \\
\text { Cases/Number Of } \\
\text { Controls }\end{array}$ & Results & Findings \\
\hline $\begin{array}{l}\text { Rothe K. et al. } 2020 \\
\text { [11] }\end{array}$ & $\begin{array}{l}\text { Retrospective } \\
\text { analysis }\end{array}$ & $\begin{array}{l}\text { Adults with } \\
\text { bacteriuria admitted } \\
\text { to the emergency } \\
\text { department }\end{array}$ & 128 UTIs/55 ABU & $\begin{array}{l}\text { PCT (Cut-off }=0.25 \\
\text { ng } / \mathrm{mL}) \\
\text { NPV } 0.962\end{array}$ & $\begin{array}{l}\text { Negative PCT could } \\
\text { be useful to identify } \\
\text { ABU }\end{array}$ \\
\hline $\begin{array}{l}\text { Li Y.-M. et al. } 2020 \\
\text { [12] }\end{array}$ & $\begin{array}{l}\text { Prospective } \\
\text { case-control study }\end{array}$ & $\begin{array}{l}\text { Adult admitted to the } \\
\text { stroke unit } \\
\text { department }\end{array}$ & 35 UTIs/151 controls & $\begin{array}{l}\text { PCT } 0.09(0.05-0.15)^{\wedge} \\
\text { in UTI vs. } 0.06 \\
(0.03-0.1)^{\wedge} \text { in Controls } \\
\text { OR }=2.25 \\
p=0.726\end{array}$ & $\begin{array}{l}\text { Despite the increase } \\
\text { in PCT level in UTIs, } \\
\text { PCT fails as } \\
\text { independent } \\
\text { predictor of UTIs }\end{array}$ \\
\hline $\begin{array}{l}\text { Levine A.R. et al. } \\
2018 \text { [13] }\end{array}$ & $\begin{array}{l}\text { Retrospective } \\
\text { analysis }\end{array}$ & $\begin{array}{l}\text { Adults admitted to } \\
\text { the emergency } \\
\text { department }\end{array}$ & 48 UTIs / 245 controls & $\begin{array}{l}\text { AUC } 0.717(p<0.001) \\
\text { PCT (Cut-off }=0.25 \\
\text { ng/mL): } \\
\text { NPV } 0.91\end{array}$ & $\begin{array}{l}\text { Negative PCT was a } \\
\text { strong predictor of } \\
\text { absence of UTIs and } \\
\text { may be useful in the } \\
\text { antibiotic } \\
\text { management }\end{array}$ \\
\hline
\end{tabular}


Table 1. Cont.

\begin{tabular}{|c|c|c|c|c|c|}
\hline $\begin{array}{c}\text { Study } \\
\text { Reference }\end{array}$ & Type of Study & Type of Patients & $\begin{array}{c}\text { Number of } \\
\text { Cases/Number Of } \\
\text { Controls }\end{array}$ & Results & Findings \\
\hline $\begin{array}{l}\text { Iftimie S. et al. } 2016 \\
\text { [14] }\end{array}$ & $\begin{array}{l}\text { Prospective } \\
\text { case-control study }\end{array}$ & $\begin{array}{l}\text { Adults with recent } \\
\text { urine catheter } \\
\text { removal }\end{array}$ & $\begin{array}{l}42 \mathrm{ACI} / 100 \text { healthy } \\
\text { subjects }\end{array}$ & $\begin{array}{l}\mathrm{PCT}(\mathrm{pg} / \mathrm{L}): \\
36.5(1-570.3)^{\prime \prime} \text { no } \\
\text { ACI vs. 51.7 } \\
(1.4-1269.1)^{\prime \prime} \text { ACI, } p= \\
0.15 . \\
\text { AUC } 0.57\end{array}$ & $\begin{array}{l}\text { PCT showed } \\
\text { considerable degree } \\
\text { of overlap between } \\
\text { groups (controls, } \\
\text { urine catheter } \\
\text { removal with and } \\
\text { without acute } \\
\text { concomitant } \\
\text { infection), a low } \\
\text { diagnostic accuracy. }\end{array}$ \\
\hline $\begin{array}{l}\text { Masajtis-Zagajewska } \\
\text { A. et al. } 2015 \text { [15] }\end{array}$ & Prospective study & $\begin{array}{l}\text { Adults admitted to } \\
\text { hospital with LUTS }\end{array}$ & $\begin{array}{l}45 \text { UTIs/ } 24 \text { healthy } \\
\text { subjects }\end{array}$ & $\begin{array}{l}\text { PCT }(\mathrm{ng} / \mathrm{mL}): \\
3.7( \pm 15.3)^{*} \text { in UTI } \\
\text { vs. } 0.06( \pm 0.02) * \text { in } \\
\text { Controls, } p<0.001 . \\
\text { AUC U-UTIs } 0.94 \\
(0.845-0.993)^{\prime \prime}, \text { AUC } \\
\text { L-UTIs 0.505 } \\
(0.185-0.575)^{\prime \prime}\end{array}$ & $\begin{array}{l}\text { PCT seems a } \\
\text { promising biomarker } \\
\text { in the diagnosis of } \\
\text { U-UTIs, but showed } \\
\text { its weakness in the } \\
\text { diagnosis of L-UTIs. }\end{array}$ \\
\hline
\end{tabular}

ABU: asymptomatic bacteriuria; NPV: negative predictive value; AUC: area under curve; ACI: acute concomitant infection; LUTS: lower urinary tract symptoms; U-UTIs: upper urinary tract infections. $\left(^{*}\right)$ variable represented as mean ( \pm standard deviation), ( $\left.{ }^{\wedge}\right)$ variable represented as median (interquartile range), $(")$ variable represented as median ( $95 \%$ confidence interval).

Specifically, the evaluated trials showed the good negative predictive value of PCT in UTIs diagnosis $[11,13]$. This aspect is relevant in clinical practice because a PCT value $<$ $0.25 \mathrm{ng} / \mathrm{mL}$ suggests the low likelihood of having UTIs. Thus, negative PCT supported general practitioners in the decision to wait for urine culture results or follow-up patient conditions before administering empirical antibiotic treatments. Conversely, high PCT levels at the moment of the clinical onset of a suspicious UTI are not a sensible marker for the diagnosis of UTIs. However, an elevated PCT should be evaluated carefully by the clinicians, especially in fragile people, because its value accurately predicts the presence of bacteraemia and bacterial load [16] and seems correlated to disease severity [14,15], regardless of the origin of the primary infection. Finally, three studies showed low accuracy and neglectable PCT changes in lower UTIs $[12,14,15]$. Those results suggest a marginal role of PCT during lower UTIs and seem congruent with the idea that PCT increases significantly during bacteremia.

\subsection{Interleukin-6}

Interleukin-6 (IL-6) is a cytokine and participates in different biological activities, including immunoregulation, inflammation, and oncogenesis. In an acute-phase reaction, IL-6 levels increase quickly in response to inflammation and infective stimuli [17]. For example, during a septic episode, IL-6 concentration can arise by 100 times over the basal concentration, which in healthy people is under $5 \mathrm{pg} / \mathrm{mL}$ [18].

Table 2 summarizes the characteristics and the main results of the 11 studies evaluating the role of IL-6 in the diagnosis of UTIs. 
Table 2. Serum and urine interleukin-6 diagnostic value in UTIs, with a target population of adults.

\begin{tabular}{|c|c|c|c|c|c|}
\hline $\begin{array}{c}\text { Study } \\
\text { Reference }\end{array}$ & Type of Study & Type of Patients & $\begin{array}{c}\text { Number of } \\
\text { Cases/Number of } \\
\text { Controls }\end{array}$ & Results & Finding \\
\hline $\begin{array}{l}\text { Gill K. et al. } 2021 \\
\text { [19] }\end{array}$ & $\begin{array}{l}\text { Prospective, blind, } \\
\text { observationalcohort } \\
\text { study }\end{array}$ & $\begin{array}{l}\text { Adult women with } \\
\text { OAS symptoms }\end{array}$ & $\begin{array}{l}24 \text { patients with } \mathrm{OAB} \\
\text { and } 22 \text { asymptomatic } \\
\text { control subjects }\end{array}$ & $\begin{array}{l}\text { The differences between } \\
\text { patients and controls in } \\
\text { urine } \mathrm{u}-\mathrm{IL}-6(\mathrm{~F}=49.0, p< \\
0.001) \text {. } \\
\mathrm{u} \text {-IL- } 6 \text { levels were } \\
\text { predicted by bacteriuria } \\
(p=0.024) \text {, and pyuria } \\
\text { count }(p<0.001) \text {, but not } \\
\text { by pain }(p=0.93) \text {, LUTS } \\
\text { score }(p=0.658) \text {, and } \\
\text { urgency }(p=0.31)\end{array}$ & $\begin{array}{l}\text { In OAB urinary u-Il-6 } \\
\text { was associated } \\
\text { with pyuria and } \\
\text { bacterial growth, } \\
\text { suggesting its } \\
\text { potential role in } \\
\text { chronic disease }\end{array}$ \\
\hline $\begin{array}{l}\text { Li Y.-M. et al. } \\
2020 \text { [12] }\end{array}$ & $\begin{array}{l}\text { Prospective } \\
\text { case-control study }\end{array}$ & $\begin{array}{l}\text { Adult admitted to the } \\
\text { stroke unit } \\
\text { department }\end{array}$ & 35 UTI/151 controls & $\begin{array}{l}\mathrm{IL}-6(\mathrm{pg} / \mathrm{mL}): \\
4.49(2.53-11)^{\wedge} \text { in UTI vs. } \\
3.23(2-4.49)^{\wedge} \text { in Controls } \\
p=0.03 \mathrm{OR}=1.175 p= \\
0.047\end{array}$ & $\begin{array}{l}\text { IL-6 increases } \\
\text { significantly during } \\
\text { UTI, and seems an } \\
\text { independent } \\
\text { predictor marker of } \\
\text { UTI }\end{array}$ \\
\hline $\begin{array}{l}\text { Gadalla A.A.H. } \\
\text { et al. } 2019 \text { [20] }\end{array}$ & Case-control study & $\begin{array}{l}\text { Adult women with at } \\
\text { least one symptom }\end{array}$ & 79 UTI/104 no UTI & $\begin{array}{l}\text { U-IL-6 (): } \\
0.5(0-2.7)^{\wedge} \text { in no UTI } \\
1.1(0-3.1)^{\wedge} \text { in UTI }\end{array}$ & $\begin{array}{l}\text { No significant change } \\
\text { in U-IL-6 between } \\
\text { symptomatic woman } \\
\text { with and without } \\
\text { UTIs }\end{array}$ \\
\hline $\begin{array}{l}\text { Kjölvmark C. } \\
\text { et al. } 2016 \text { [21] }\end{array}$ & $\begin{array}{l}\text { Prospective } \\
\text { case-control study }\end{array}$ & $\begin{array}{l}\text { Elderly ( } \geq 80 \text { years } \\
\text { old) assisted in a } \\
\text { nurse home } \\
\text { residence. }\end{array}$ & $49 \mathrm{UTI} / 38 \mathrm{ABU}$ & $\begin{array}{l}\text { U-IL-6 } 150(4-630)^{\wedge} \text { in UTI } \\
\text { vs. } 4(4-13)^{\wedge} \text { in ABU } p< \\
0.01 . \\
\text { U-IL-6 }>30 \mathrm{pg} / \mathrm{mL} \text { PPV } \\
\text { and NPV of L-UTI were, } \\
\text { respectively, } 0.56 \text { and } 0.68 \text {. } \\
\text { PPV and NPV of U-UTI } \\
\text { were } 0.74 \text { and } 0.87 \text {, } \\
\text { respectively. }\end{array}$ & $\begin{array}{l}\text { U-IL-6 } 6 \text { increases } \\
\text { significantly during } \\
\text { UTI. U-IL- } 6 \text { seems } \\
\text { clinically useful to } \\
\text { discriminate ABU } \\
\text { from U-UTI, while its } \\
\text { utility seems } \\
\text { inconsistent in the } \\
\text { discrimination } \\
\text { between ABU and } \\
\text { L-UTI }\end{array}$ \\
\hline $\begin{array}{l}\text { Sunden F. and } \\
\text { Wullt B. } 2016 \text { [22] }\end{array}$ & $\begin{array}{l}\text { Prospective } \\
\text { case-control study }\end{array}$ & $\begin{array}{l}\text { Adult assisted in a } \\
\text { nurse home } \\
\text { residence. }\end{array}$ & $22 \mathrm{UTI} / 35 \mathrm{ABU}$ & $\begin{array}{l}\text { U-IL-6 (ng/L) } 227 \\
(17-1400)^{\prime \prime} \text { in UTI vs. } 30 \\
(8-86)^{\prime \prime} \text { in ABU }\end{array}$ & $\begin{array}{l}\text { U-IL-6 increases } \\
\text { significantly in UTIs }\end{array}$ \\
\hline $\begin{array}{l}\text { Van der Starre } \\
\text { et al. } 2015 \text { [23] }\end{array}$ & Case-control study & $\begin{array}{l}\text { Adults with LUTS } \\
\text { and fever }\end{array}$ & $\begin{array}{l}46 \text { bacteriaemic } \\
\text { UTI/45 No } \\
\text { bacteriaemic UTI/45 } \\
\text { controls }\end{array}$ & $\begin{array}{l}\mathrm{u}-\mathrm{IL}-6(\mathrm{pg} / \mathrm{umol}) \text { was } \\
\text { higher in UTIs }(p<0.001) \text {. } \\
\text { No significant difference } \\
\text { was found between } \\
\text { bacteriaemic and no } \\
\text { bacteriaemic UTI patients } \\
(p=0.21)\end{array}$ & $\begin{array}{l}\text { u-IL-6 levels are } \\
\text { different between } \\
\text { controls and UTI } \\
\text { patients, although it } \\
\text { does not distinguish } \\
\text { bacteraemia status }\end{array}$ \\
\hline $\begin{array}{l}\text { Masajtis- } \\
\text { Zagajewska A. } \\
\text { et al. } 2015 \text { [15] }\end{array}$ & Prospective study & $\begin{array}{l}\text { Adults with LUTS } \\
\text { admitted to hospital, } \\
\text { and adult healthy } \\
\text { subjects }\end{array}$ & $\begin{array}{l}45 \mathrm{UTI} / 32 \mathrm{U}-\mathrm{UTI}, / 24 \\
\text { controls }\end{array}$ & $\begin{array}{l}\text { IL-6 (pg/mL): } \\
84.8( \pm 67) \text { in U-UTI vs. } \\
3.1( \pm 1.6)^{*} \text { in controls, } p \\
<0.001 \\
22.5( \pm 1.6) \text { in L-UTI vs. } \\
3.1( \pm 1.6)^{*} \text { in controls, } p \\
<0.001 \\
84.8( \pm 67) \text { in U-UTI vs. } \\
22.5( \pm 1.6)^{*} \text { in controls, } p \\
<0.001\end{array}$ & $\begin{array}{l}\text { IL-6 seems a } \\
\text { promising biomarker } \\
\text { to assess UTI } \\
\text { diagnosis. This } \\
\text { preliminary study } \\
\text { suggested IL-6 levels } \\
\text { could discriminate } \\
\text { between U and } \\
\text { L-UTI. } \\
\text { Limits: the } \\
\text { comparison with } \\
\text { healthy people could } \\
\text { overestimate its } \\
\text { ability in doubtful } \\
\text { cases }\end{array}$ \\
\hline
\end{tabular}


Table 2. Cont.

\begin{tabular}{|c|c|c|c|c|c|}
\hline $\begin{array}{c}\text { Study } \\
\text { Reference }\end{array}$ & Type of Study & Type of Patients & $\begin{array}{c}\text { Number of } \\
\text { Cases/Number of } \\
\text { Controls }\end{array}$ & Results & Finding \\
\hline $\begin{array}{l}\text { Sundvall P.D. } \\
\text { et al. } 2014 \text { [24] }\end{array}$ & $\begin{array}{l}\text { Cross sectional } \\
\text { study }\end{array}$ & $\begin{array}{l}\text { Elderly ( } \geq 65 \text { years) } \\
\text { assisted in a nurse } \\
\text { home residence. }\end{array}$ & $\begin{array}{l}135 \text { positive urine } \\
\text { culture } / 286 \text { negative } \\
\text { urine culture }\end{array}$ & $\begin{array}{l}\text { U-IL-6 }(\mathrm{ng} / \mathrm{L}) 2.5(1-5.7)^{\wedge} \\
\text { in positive urine culture } \\
\text { vs. } 1.3(0.6-2.8)^{\wedge} \text { in } \\
\text { negative urine culture } p< \\
0.001\end{array}$ & $\begin{array}{l}\text { In positive urine } \\
\text { cultures, U-IL-6 was } \\
\text { significantly higher } \\
\text { than in negative urine } \\
\text { cultures, but the study } \\
\text { did not intercept any } \\
\text { significant relationship } \\
\text { with the symptoms }\end{array}$ \\
\hline $\begin{array}{l}\text { Grönberg- } \\
\text { Hernández J. } \\
\text { et al. } 2011 \text { [25] }\end{array}$ & $\begin{array}{l}\text { Placebo-controlled } \\
\text { study }\end{array}$ & $\begin{array}{l}\text { Adults, who receveid } \\
\text { therapeutic } \\
\text { inoculation with } E \text {. } \\
\text { coli } 83972\end{array}$ & $\begin{array}{l}23 \text { patients, } \\
223 \text { bacteriuric urine } \\
\text { samples } \\
68 \text { sterile urine } \\
\text { samples }\end{array}$ & $\begin{array}{l}\mathrm{u}-\mathrm{IL}-6(\mathrm{ng} / \mathrm{L}): \\
5.5( \pm 1)^{\wedge} \text { in ABU } \\
3.2( \pm 0.5)^{\wedge} \text { in sterile urine, } \\
p=0.3\end{array}$ & $\begin{array}{l}\text { No significant } \\
\text { difference in u-IL-6 } \\
\text { between the patients } \\
\text { who developed ABU } \\
\text { and those who did not. }\end{array}$ \\
\hline $\begin{array}{l}\text { Rodhe N. et al. } \\
2009 \text { [11] }\end{array}$ & Case-control study & $\begin{array}{l}\text { Elderly ( } \geq 80 \text { years } \\
\text { old) }\end{array}$ & $\begin{array}{l}16 \mathrm{~L}-\mathrm{UTI} / 24 \mathrm{ABU} / 20 \\
\text { controls }\end{array}$ & $\begin{array}{l}\text { U-IL-6 }(\mathrm{ng} / \mathrm{mL}): \\
54.7(10.7-443)^{\wedge} \text { in L-UTI } \\
\text { vs. } 14.4(7.1-37.4)^{\wedge} \text { In } \\
\text { ABU } \\
11.7(5.6-69.1)^{\wedge} \text { in } \\
\text { controls. } \\
\text { Sensitivity: } 0.88(60-98)^{\prime \prime} \\
\text { Specificity: } 0.96(77-100)^{\prime \prime}\end{array}$ & $\begin{array}{l}\text { U-IL- } 6 \text { can improve the } \\
\text { diagnostic process of } \\
\text { UTI }\end{array}$ \\
\hline $\begin{array}{l}\text { Ciszek M. et al. } \\
2006 \text { [26] }\end{array}$ & $\begin{array}{l}\text { Prospective } \\
\text { case-control study }\end{array}$ & $\begin{array}{l}\text { Kidney transplant } \\
\text { recipients with } \\
\text { bacteriuria }\end{array}$ & $\begin{array}{l}5 \mathrm{UTI} / 22 \mathrm{ABU} / 25 \\
\text { controls }\end{array}$ & $\begin{array}{l}\text { U-IL-6 }(\mathrm{pg} / \mathrm{mg} \\
\text { creatinine): } \\
3.92(0.22-17.33)^{\wedge} \text { in ABU } \\
15.71(3.6-246.95)^{\wedge} \text { in } \\
\text { UTIs } \\
2.54(0.34-78.41)^{\wedge} \text { in } \\
\text { control }\end{array}$ & $\begin{array}{l}\text { No significant } \\
\text { difference was detected } \\
\text { in U-IL-6 levels } \\
\text { between ABU patients } \\
\text { and controls, while its } \\
\text { levels increase } \\
\text { significantly in UTI } \\
\text { patients }\end{array}$ \\
\hline $\begin{array}{l}\text { Olszyna D.P. et al. } \\
2001 \text { [27] }\end{array}$ & Case-control study & $\begin{array}{l}\text { Adults who received } \\
\text { a urinary catheter }\end{array}$ & $\begin{array}{l}10 \text { UTIs patients } / 20 \\
\text { no-UTI patients }\end{array}$ & $\begin{array}{l}\text { u-IL-6 value in UTIs and } \\
\text { in non UTIs not reported }\end{array}$ & $\begin{array}{l}\mathrm{u}-\mathrm{IL}-6 \text { is released in } \\
\text { the urine of } \\
\text { postoperative patients } \\
\text { who have a } \\
\text { urinary catheter, } \\
\text { irrespective of the } \\
\text { presence of a UTI. }\end{array}$ \\
\hline $\begin{array}{l}\text { Nicolle L.E. et al. } \\
1993 \text { [28] }\end{array}$ & $\begin{array}{l}\text { Prospective } \\
\text { case-control study }\end{array}$ & $\begin{array}{l}\text { Elderly ( } \geq 65 \text { years) } \\
\text { assisted in a nurse } \\
\text { home residence. }\end{array}$ & $\begin{array}{l}51 \text { ABU / } 34 \text { Fever no } \\
\text { UTI/9 UTI }\end{array}$ & $\begin{array}{l}\text { u-IL- } 6 \text { was detected in } \\
43 \% \text { of asymptomatic } \\
\text { subjects and in } 78 \% \text { of } \\
\text { UTI patients }\end{array}$ & $\begin{array}{l}\text { U-IL-6 was identified } \\
\text { more frequently in } \\
\text { bacteriuric specimen. }\end{array}$ \\
\hline $\begin{array}{l}\text { Ko Y.C. et al. } \\
1993 \text { [29] }\end{array}$ & Case-control study & Adults with LUTS & $\begin{array}{l}113 \text { UTI patients } / 74 \\
\text { no UTI patients } / 20 \\
\text { healthy subjects }\end{array}$ & $\begin{array}{l}\mathrm{u}-\mathrm{IL}-6(\mathrm{pg} / \mathrm{mL}) \text { : } \\
92.5( \pm 43.3)^{\wedge} \text { in UTI vs } \\
\text { undetectable in control } \\
\text { group }\end{array}$ & $\begin{array}{l}\mathrm{u} \text {-IL-6 seems to } \\
\text { increase in UTI }\end{array}$ \\
\hline
\end{tabular}

ABU = asymptomatic bacteriuria; LUTS = lower urinary tract symptoms; U-UTIs = upper urinary tract infection: $\mathrm{OAB}=$ over acting bladder; NPV = negative predictive value; $\mathrm{PPV}=$ positive predictive value; $\mathrm{AUC}=$ area under curve; $\mathrm{OR}=$ odds ratio. $\left({ }^{*}\right)$ variable represented as mean $\left( \pm\right.$ standard deviation), $\left(^{\wedge}\right)$ variable represented as median (interquartile range), $\left({ }^{\wedge}\right)$ variable represented as median (min-max), $\left({ }^{\prime \prime}\right)$ variable represented as median (95\% confidence interval).

UTIs induce a significant increase in serum IL-6, and its level could differentiate lower and upper UTIs. Unfortunately, only two small studies evaluated this aspect and in two different clinical settings $[15,21]$

Urine IL-6 was explored by eleven small studies [11,12,15,19-23,26-28], usually performed in the elderly. Not all studies suggested a significant increase in urine IL-6 during UTIs, and the studies were too heterogenous to obtain a univocal recommendation. Currently, some studies have shown a significant increase in urine IL-6 in the case of pyelonephritis and bacteriemia $[15,21]$; others suggested a significant increase also in lower UTIs [11,22-26,29]; others concluded there are no significant differences in urine IL-6 be- 
tween UTIs and asymptomatic bacteriuria [20,21,27,28]. Probably, urine IL-6 increases proportionally to inflammatory status related to urinary infection. This hypothesis could explain the heterogeneity in the results among the studies, which evaluated urine IL-6 levels in a different clinical setting of UTI.

Finally, only two studies evaluated its accuracy [11,21], and only one [21] proposed a possible cut-off for urine IL-6 level in the diagnosis of UTIs. Therefore, there is insufficient evidence to support its use as UTI predictor in clinical practice. Although considering those results promising, new studies should be performed to estimate its actual accuracy in UTI diagnosis.

\subsection{Neutrophil Gelatinase-Associated Lipocalin}

Neutrophil gelatinase-associated lipocalin (NGAL) is a $21-\mathrm{kD}$ protein of the lipocalin superfamily. During bacterial infections, NGAL is secreted by neutrophils to limit bacterial growth. Specifically, NGAL binds bacterial siderophores limiting the iron supply and consequently the bacterial cellular process. Furthermore, NGAL seems to promote differentiation of renal epithelial cells and its predictive value in acute kidney injury has been proven in recent years [30].

Table 3 shows the characteristics and the main results of the four studies evaluating the role of urine NGAL value in the diagnosis of UTIs.

Table 3. Urine NGAL diagnostic value in UTIs; target population: adults.

\begin{tabular}{|c|c|c|c|c|c|}
\hline $\begin{array}{c}\text { Study } \\
\text { Reference }\end{array}$ & Type of Study & Type of Patients & $\begin{array}{c}\text { Number of } \\
\text { Cases/Number of } \\
\text { Controls }\end{array}$ & Results & Finding \\
\hline $\begin{array}{l}\text { Gadalla A.A.H. } \\
\text { et al. } 2019 \text { [20] }\end{array}$ & $\begin{array}{l}\text { Case-control } \\
\text { study }\end{array}$ & $\begin{array}{l}\text { Adult women with } \\
\text { at least one } \\
\text { symptom }\end{array}$ & 79 UTI/104 no UTI & $\begin{array}{l}\text { u-NGAL }(\mathrm{ng} / \mathrm{mL}) \text { : } \\
5.5(0-5.9)^{\wedge} \text { in UTIs } \\
4.5(0-5.9)^{\wedge} \text { in No UTIs } \\
\text { Combined to other } \\
\text { immunological biomarkers: } \\
\text { AUC 0.81 }(0.68-0.94)^{\prime \prime} \\
\text { PPV } 0.82(0.55-0.95)^{\prime \prime} \\
\text { NPV 0.76 }(0.58-0.88)^{\prime \prime}\end{array}$ & $\begin{array}{l}\text { The use of u-NGAL } \\
\text { associated with other } \\
\text { immunological biomarkers } \\
\text { (CXCL8, MMP9, IL1 B) } \\
\text { seems a good predictor of } \\
\text { UTIs. }\end{array}$ \\
\hline $\begin{array}{l}\text { Price J.R. et al. } \\
2017 \text { [31] }\end{array}$ & $\begin{array}{l}\text { Prospective } \\
\text { case-control } \\
\text { study }\end{array}$ & $\begin{array}{l}\text { Adult women with } \\
\text { LUTS }\end{array}$ & $\begin{array}{l}50 \text { UTI/ } 50 \text { healthy } \\
\text { subjects }\end{array}$ & $\begin{array}{l}\text { u-NGAL }(\mathrm{ng} / \mathrm{mL}) \text { : } \\
88.9(40.7-193.4)^{\wedge} \text { in UTIs vs } \\
3.6(2.5-8.1)^{\wedge} \text { in controls, } p< \\
0.001 \\
\text { AUC for UTIs = } 0.973 \\
\text { Cut-off } 23.9 \mathrm{ng} / \mathrm{mL} \text { : } \\
\text { Sensitivity } 98 \% \text {, Specificity } \\
100 \%\end{array}$ & $\begin{array}{l}\mathrm{u} \text {-NGAL in women seems } \\
\text { to have an excellent } \\
\text { accuracy to detect UTIs, } \\
\text { showing a better AUC } \\
\text { compared with } \\
\text { u-leukocytis (AUC 0.84) } \\
\text { and u-nitrates (AUC 0.6927) }\end{array}$ \\
\hline $\begin{array}{l}\text { Urbschat A. et al. } \\
2014 \text { [32] }\end{array}$ & $\begin{array}{l}\text { Prospective } \\
\text { case-control } \\
\text { study }\end{array}$ & $\begin{array}{l}\text { Aduls with LUTS } \\
\text { with or without } \\
\text { fever }\end{array}$ & $\begin{array}{l}30 \text { U-UTIs / } 29 \\
\text { L-UTIs / } 38 \text { healthy } \\
\text { subjects }\end{array}$ & $\begin{array}{l}\text { u-NGAL }(\mathrm{ng} / \mathrm{mL}) \text { : } \\
111.07( \pm 114.29)^{*} \text { in U-UTI } \\
\text { vs. } 47.78( \pm 58.6)^{*} \text { in healthy } \\
\text { subjects, } p<0.01 \\
100.61( \pm 95.38)^{*} \text { in } \\
\text { L-UTI47.78 }( \pm 58.6) * \text { in } \\
\text { healthy subjects, } p<0.05 \\
111.07( \pm 114.29)^{*} \text { in U-UTI } \\
\text { vs. } \\
100.61( \pm 95.38)^{*} \text { in L-UTI, } p \\
=\text { NS }\end{array}$ & $\begin{array}{l}\text { u-NGAL increases } \\
\text { significantly in UTIs. } \\
\text { However, NGAL levels do } \\
\text { not allow to discriminate } \\
\text { between U-UTI and L-UTI }\end{array}$ \\
\hline $\begin{array}{l}\text { Decavele A.S. } \\
\text { et al. } 2011 \text { [33] }\end{array}$ & $\begin{array}{l}\text { Prospective } \\
\text { case-control } \\
\text { study }\end{array}$ & $\begin{array}{l}\text { Adults admitted to } \\
\text { hospital and } \\
\text { outpatients }\end{array}$ & $\begin{array}{l}110 \mathrm{UTI} / 104 \\
\text { controls }\end{array}$ & $\begin{array}{l}\mathrm{u}-\mathrm{NGAL}(\mathrm{ng} / \mathrm{mL}) \text { and } \\
\text { leukocyturia: rho0.518 } p< \\
0.001 \\
\mathrm{u}-\mathrm{NGAL}(\mathrm{ng} / \mathrm{mL}) \text { and } \\
\text { urinary bacterial count: rho } \\
0.243 p<0.001\end{array}$ & $\begin{array}{l}\text { The authors suggested the } \\
\text { correction of u-NGAL } \\
\text { levels considering } \\
\text { leukocyturia in the urine }\end{array}$ \\
\hline
\end{tabular}
represented as mean ( \pm standard deviation), $\left({ }^{\wedge}\right)$ variable represented as median (interquartile range), $\left({ }^{\wedge}\right)$ variable represented as median (min-max), (“) variable represented as median ( $95 \%$ confidence interval). 
The first reports about urine NGAL accuracy in UTI diagnosis seem promising, especially in women. Specifically, Price et al. showed how u-NGAL has excellent accuracy in UTI diagnosis in a cohort of 100 women, 50 adult women with UTIs and 50 healthy adult women [31]. However, in our opinion, such remarkable results are related to the nature of the control group (constituted by healthy women), which can magnify the difference with UTI women and the accuracy of UNGAL as a biomarker of UTIs. Moreover, Gadalla et al. showed how u-NGAL performance could be implemented by combining its use with other immunological biomarkers (IL-8, IL-1alfa, and matrix metalloproteinase-8), even comparing symptomatic women with UTIs and without UTIs [20].

Nevertheless, currently, the number of studies and the number of patients enrolled do not allow to suggest its clinical use in UTI diagnosis.

\subsection{Urinary Adenosine-5'-Triphosphate}

Urinary adenosine- $5^{\prime}$-triphosphate (ATP) is an organic compound that has the primary role to provide energy in many biological intracellular processes. Specifically, during UTIs, ATP release in a urine sample is increased by inflammatory cells and bacteria [34]. Consequently, its detection in the urine could be a useful biomarker of the infective process.

Table 4 summarizes the characteristics and the main results of the three studies evaluating the role of urine ATP levels in the diagnosis of UTIs.

Table 4. Urine ATP diagnostic value in UTIs; target population: adults.

\begin{tabular}{|c|c|c|c|c|c|}
\hline $\begin{array}{c}\text { Study } \\
\text { Reference }\end{array}$ & Type of Study & Type of Patients & $\begin{array}{c}\text { Number of } \\
\text { Cases/Number of } \\
\text { Controls }\end{array}$ & Results & Finding \\
\hline $\begin{array}{l}\text { Gill K. et al. } 2015 \\
\text { [35] }\end{array}$ & $\begin{array}{l}\text { Prospective } \\
\text { cross-sectional } \\
\text { observational study }\end{array}$ & Adults with LUTS & $\begin{array}{l}340 \text { LUTS } / 75 \text { healthy } \\
\text { subjects }\end{array}$ & $\mathrm{AUC}=0.6$ & $\begin{array}{l}\text { U-ATP is an } \\
\text { unconvincing clinical } \\
\text { diagnostic marker. }\end{array}$ \\
\hline $\begin{array}{l}\text { Lundin A. et al. } \\
1989 \text { [36] }\end{array}$ & Case-control study & $\begin{array}{l}\text { Adult women with } \\
\text { LUTS }\end{array}$ & $\begin{array}{l}753 \text { women with } \\
\text { positive urine } \\
\text { culture/ } 373 \text { women } \\
\text { with no diagnostic } \\
\text { urine culture }\end{array}$ & $\begin{array}{l}\mathrm{NPV}=0.91 \\
\mathrm{PPV}=0.93\end{array}$ & $\begin{array}{l}\text { A low ATP value seems } \\
\text { to exclude UTI, while a } \\
\text { high ATP value } \\
\text { suggests UTI diagnosis. } \\
\text { Limit: the ATP test is } \\
\text { too complicated to } \\
\text { become widely } \\
\text { accepted. }\end{array}$ \\
\hline $\begin{array}{l}\text { Hallander H.O. } \\
\text { et al. } 1986 \text { [37] }\end{array}$ & Case-control study & Adults with LUTS & $\begin{array}{l}136 \text { bacteriuric } \\
\text { patients } / 645 \\
\text { no-bacteriuric } \\
\text { patients }\end{array}$ & $\begin{array}{l}\text { Sensitivity } 0.9, \\
\text { Specificity } 0.94, \text { PPV } \\
0.76, \text { NPV } 0.98 \text { to detect } \\
\text { bacteriuria } \\
\text { Sensitivity } 0.7, \\
\text { Specificity } 0.89, \text { PPV } \\
0.91, \text { NPV } 0.99 \text { to detect } \\
\text { positive urine culture }\end{array}$ & $\begin{array}{l}\text { u-ATP levels predicts a } \\
\text { positive urine culture. } \\
\text { Better diagnostic } \\
\text { efficiency can be } \\
\text { obtained in } \\
\text { combination with other } \\
\text { tests, such as the nitrite } \\
\text { and dipslide test. }\end{array}$ \\
\hline
\end{tabular}

LUTS = lower urinary tract symptoms; NPV = negative predictive value; $\mathrm{PPV}=$ positive predictive value; $\mathrm{AUC}=$ area under curve.

These studies have ambiguous results. Specifically, whereas older studies suggested a good performance of ATP as a surrogate marker of bacteriuria [36,37], the latest reports failed to prove its utility as a surrogate marker of UTIs [35]. Likely, these inconclusive results could be related to differences in the methods of ATP analysis and the clinical setting.

\subsection{Proadrenomedullin}

Proadrenomedullin (proADM) plays an important role in the inflammation and infective process and showed a good performance as a new biomarker in septic disease [38]. Whereas some studies evaluated proADM impact in the treatment management of UTIs [39-41], no study evaluated its possible role in the discrimination between UTIs and ABU. 


\subsection{Beta2-Microglobulin}

Beta2-microglobulin (B2-M) is a protein with a molecular weight of $11.8 \mathrm{KD}$, passes easily through the glomerular membrane and is almost completely reabsorbed and metabolized by the tubules. Urine $132-\mathrm{M}$ increases during tubular damage and, consequently, it could be a sensitive marker of upper UTIs.

Table 5 summarizes the characteristics and the main results of the four studies evaluating the role of urine $\mathrm{B} 2-\mathrm{M}$ as a biomarker of UTIs.

Table 5. Urine $ß 2-\mathrm{M}$ diagnostic value in UTIs, target population adults.

\begin{tabular}{|c|c|c|c|c|c|}
\hline $\begin{array}{c}\text { Study } \\
\text { Reference }\end{array}$ & Type of Study & Type of Patients & $\begin{array}{c}\text { Number of } \\
\text { Cases/Number of } \\
\text { Controls }\end{array}$ & Results & Finding \\
\hline $\begin{array}{l}\text { Sandberg T. et al. } \\
1986 \text { [42] }\end{array}$ & $\begin{array}{l}\text { Prospective } \\
\text { case-control study }\end{array}$ & $\begin{array}{l}\text { Adults } \\
\text { Women with LUTS } \\
\text { with or without fever }\end{array}$ & $\begin{array}{l}105 \text { U-UTIs } \\
32 \text { L-UTIs } \\
12 \text { patients with fever } \\
\text { of non-renal origin }\end{array}$ & $\begin{array}{l}67 \% \text { of U-UTI were } \\
\text { associated with } § 2-\mathrm{M} \\
\geq 50 \mathrm{mg} / \mathrm{mol} \\
\text { creatinine, only } 6 \% \text { of } \\
\text { L-UTIs has } \Omega 2-\mathrm{M} \geq \\
50 \mathrm{mg} / \mathrm{mol} \text { creatinine }\end{array}$ & $\begin{array}{l}\text { An increased } ß 2-\mathrm{M} \geq \\
50 \mathrm{mg} / \mathrm{mol} \text { creatinine } \\
\text { is associated with } \\
\text { pyelonephritis but } \\
\text { not with cystitis }\end{array}$ \\
\hline $\begin{array}{l}\text { Schardijn G. et al. } \\
1984 \text { [43] }\end{array}$ & $\begin{array}{l}\text { Prospective } \\
\text { case-control study }\end{array}$ & Adults with LUTS & $\begin{array}{l}19 \text { U-UTIs / } 15 \\
\text { L-UTIs/44 controls }\end{array}$ & $\begin{array}{l}\text { ß2-M (ug/die): } \\
8509(4890-60,000)^{* *} \\
\text { in U-UTIs } \\
162(33-308)^{* *} \text { in } \\
\text { L-UTI } \\
110(33-361)^{* *} \text { in } \\
\text { controls }\end{array}$ & $\begin{array}{l}\text { Not significant to } \\
\text { improve UTI } \\
\text { diagnosis, likely } \\
\text { useful to suggest } \\
\text { U-UTIs }\end{array}$ \\
\hline $\begin{array}{l}\text { Mengoli C. et al. } 1982 \\
\text { [44] }\end{array}$ & Case-control study & $\begin{array}{l}\text { Adults with } \\
\text { bacteriuria }\end{array}$ & $\begin{array}{l}19 \text { U-UTIs/15 L-UTIs } \\
\text { and ABU }\end{array}$ & $\begin{array}{l}\circledR 2-\mathrm{M} \text { (ug/die): } \\
1471( \pm 320)^{*} \text { in } \\
\text { U-UTIs } \\
71( \pm 14)^{*} \text { in L-UTIs e } \\
\text { ABU }\end{array}$ & $\begin{array}{l}\text { Not significant to } \\
\text { improve UTI } \\
\text { diagnosis, likely } \\
\text { useful to suggest } \\
\text { U-UTIs }\end{array}$ \\
\hline $\begin{array}{l}\text { Schardijn G. et al. } \\
1979[45]\end{array}$ & $\begin{array}{l}\text { Prospective } \\
\text { case-control study }\end{array}$ & Adults with LUTS & $\begin{array}{l}10 \text { U-UTsI/14 } \\
\text { L-UTIs/20 controls }\end{array}$ & $\begin{array}{l}\text { B2-M (ug/die): } \\
3249(624-9500)^{* *} \text { in } \\
\text { U-UTIs } \\
170(33-325)^{* *} \text { in } \\
\text { L-UTIs } \\
112(33-363)^{* *} \text { in } \\
\text { controls }\end{array}$ & $\begin{array}{l}\text { Not significant to } \\
\text { improve UTI } \\
\text { diagnosis, likely } \\
\text { useful to suggest } \\
\text { U-UTIs }\end{array}$ \\
\hline
\end{tabular}

LUTS = lower urinary tract symptoms; $\mathrm{ABU}$ = asymptomatic bacteriuria; L-UTIs = lower urinary tract infections U-UTIs = upper urinary tract infection. $\left(^{*}\right)$ variable represented as mean $\left( \pm\right.$ standard deviation), $\left({ }^{* *}\right)$ variable represented as mean (min-max).

All the studies on $\mathrm{B} 2-\mathrm{M}$ were published before 1986. All the studies focused on the ability of $\mathrm{B2}-\mathrm{M}$ to discriminate between upper and lower UTIs [42-45]. As expected, no significant difference was found between lower UTIs and ABU. Consequently, its use in the diagnosis of UTIs should not be suggested.

\subsection{Chemokines}

Chemokines (ChKs) are small cytokines secreted by cells that induce directional movement of specific cell populations, such as leukocytes, endothelial and epithelial cells, to inflamed tissues. There are four different subgroups of $\mathrm{ChK}$ : CXC, CC, C, and CX3C. Specifically, CXCs are potent neutrophil/natural killer activators, while CC induce chemotaxis of $\mathrm{T}$ cell and monocytes.

Table 6 summarizes the characteristics and the main results of the eight studies evaluating the role of ChKs as a biomarker of UTIs. 
Table 6. Serum and urine chemokines diagnostic value in UTIs; target population: adults.

\begin{tabular}{|c|c|c|c|c|c|}
\hline $\begin{array}{c}\text { Study } \\
\text { Reference }\end{array}$ & Type of Study & Type of Patients & $\begin{array}{c}\text { Number of } \\
\text { Cases/Number of } \\
\text { Controls }\end{array}$ & Results & Finding \\
\hline $\begin{array}{l}\text { Gadalla A.A.H. } \\
\text { et al. } 2019 \text { [20] }\end{array}$ & $\begin{array}{l}\text { Case-control } \\
\text { study }\end{array}$ & $\begin{array}{l}\text { Adult women with } \\
\text { at least one } \\
\text { symptom }\end{array}$ & 79 UTI/104 no UTI & $\begin{array}{l}\text { u-CxCL8 (): } \\
2(0-3.9)^{\wedge} \text { in No-UTI } \\
3.1(0.8-4.6)^{\wedge} \\
\text { Combined with other } \\
\text { immunological biomarkers: } \\
\text { AUC } 0.81(0.68-0.94)^{\prime \prime} \\
\text { PPV } 0.82(0.55-0.95)^{\prime \prime} \\
\text { NPV } 0.76(0.58-0.88)^{\prime \prime}\end{array}$ & $\begin{array}{l}\text { The use of u- CxCL8 } \\
\text { associated with other } \\
\text { urinary immunological } \\
\text { biomarkers (NGAL, MMP9, } \\
\text { and IL1 B) seems a good } \\
\text { predictor of UTIs. }\end{array}$ \\
\hline $\begin{array}{l}\text { Tyagi P. et al. } \\
2016 \text { [46] }\end{array}$ & $\begin{array}{l}\text { Prospective } \\
\text { case-control } \\
\text { study }\end{array}$ & Adults & $\begin{array}{l}62 \text { UTI patients / } \\
59 \text { OAB patients / } \\
26 \text { Control }\end{array}$ & $\begin{array}{l}\text { u-CXCL1 (target } 20 \\
\text { pg/mL): AUC } 0.71 \\
\text { Sensibility } 0.5968, \\
\text { Specificity } 0.8877 . \\
\text { u-CXCL8 (target } 20 \\
\text { pg/mL): AUC } 0.71 \\
\text { Sensibility } 0.6538, \\
\text { Specificity } 0.7097 . \\
\text { u-CXCL10 (target } 20 \\
\text { pg/mL): AUC } 0.54 \\
\text { Sensibility } 0.3864, \\
\text { Specificity } 0.6271 .\end{array}$ & $\begin{array}{l}\text { Significant } \\
\text { elevation in u-CXCL-1, } \\
\mathrm{u}-\mathrm{CXCL}-8 \text {, and } \mathrm{u}-\mathrm{CXCL}-10 \\
\text { together were seen in UTIs } \\
\text { relative to OAB and } \\
\text { asymptomatic controls. } \\
\text { Urinary chemokines } \\
\text { highlight molecular } \\
\text { differences } \\
\text { in the overlapping } \\
\text { symptoms of UTIs and } \\
\text { OAB. }\end{array}$ \\
\hline $\begin{array}{l}\text { Iftimie S. et al. } \\
2016 \text { [14] }\end{array}$ & $\begin{array}{l}\text { Prospective } \\
\text { case-control } \\
\text { study }\end{array}$ & $\begin{array}{l}\text { Adults with recent } \\
\text { urine catheter } \\
\text { removal }\end{array}$ & $\begin{array}{l}42 \mathrm{ACI} \\
\text { patients } / 100 \\
\text { healthy subjects }\end{array}$ & $\begin{array}{l}\mathrm{u}-\mathrm{CCL} 2(\mathrm{pg} / \mathrm{L}): \\
209.71(115.7-357.2)^{\wedge} \mathrm{NO} \\
\text { ACI vs. } 183.3 \\
(104.6-329.5)^{\wedge}, p=0.295 \\
\text { AUC } 0.55\end{array}$ & $\begin{array}{l}\text { u-CCL2 showed } \\
\text { considerable degree of } \\
\text { overlap between the groups } \\
\text { (controls, urine catheter } \\
\text { removal with and without } \\
\text { acute concomitant } \\
\text { infection), and a low } \\
\text { diagnostic accuracy. }\end{array}$ \\
\hline $\begin{array}{l}\text { Rodhe N. et al. } \\
2009 \text { [11] }\end{array}$ & $\begin{array}{l}\text { Case-control } \\
\text { study }\end{array}$ & $\begin{array}{l}\text { Elderly ( } \geq 80 \text { years } \\
\text { old) }\end{array}$ & $\begin{array}{l}16 \mathrm{~L}-\mathrm{UTI} / 24 \\
\mathrm{ABU} / 20 \text { controls }\end{array}$ & $\begin{array}{l}\mathrm{u}-\mathrm{CXCL}-1 \text { ( }>150 \mathrm{pg} / \mathrm{mg} \\
\text { Creat): sensitivity } 0.69, \\
\text { specificity } 0.79 \\
\text { u-CXCL-8 }(>285 \mathrm{pg} / \mathrm{mg} \\
\text { Creat): sensitivity } 0.63, \\
\text { specificity } 0.96\end{array}$ & $\begin{array}{l}\mathrm{u}-\mathrm{CXCL}-1 \text { and } \mathrm{u}-\mathrm{CXCL}-8 \\
\text { were highly increased in } \\
\text { patients with L-UTI. The } \\
\text { measurement of } \mathrm{u}-\mathrm{CXCL}-1 \\
\text { and } \mathrm{u}-\mathrm{CXCL}-8 \text { can improve } \\
\text { the diagnostic process of } \\
\text { UTIs. }\end{array}$ \\
\hline $\begin{array}{l}\text { Hawn T.R. et al. } \\
2009 \text { [47] }\end{array}$ & $\begin{array}{l}\text { Cross-sectional } \\
\text { study }\end{array}$ & $\begin{array}{l}\text { Adult women with } \\
\text { and without a } \\
\text { history of recurrent } \\
\text { L-UTIs and U-UTIs }\end{array}$ & $\begin{array}{l}391 \text { women } \\
\text { with } \mathrm{ABU} / 731 \\
\text { without } \mathrm{ABU}\end{array}$ & 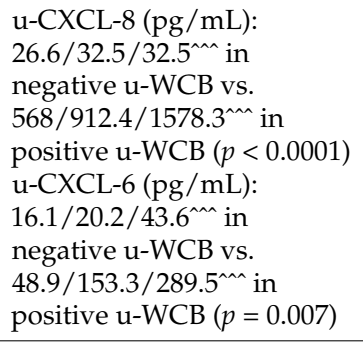 & $\begin{array}{l}\text { The urinary levels of } \\
\mathrm{u}-\mathrm{CXCL}-8 \text { and } \mathrm{u}-\mathrm{CXCL}-6 \\
\text { were associated with higher } \\
\text { neutrophil levels }\end{array}$ \\
\hline $\begin{array}{l}\text { Godaly G. et al. } \\
2007 \text { [48] }\end{array}$ & $\begin{array}{l}\text { Prospective } \\
\text { case-control } \\
\text { study }\end{array}$ & Adults & $\begin{array}{l}29 \text { E.coli UTIs / } \\
27 \text { healthy subjects }\end{array}$ & $\begin{array}{l}\text { u-CXCL-1 } 0.214(0.0-7.4)^{\wedge} \\
\mathrm{u}-\mathrm{C} \text { CL-5 } 0.16(0.0-1.8)^{\wedge} \\
\mathrm{u}-\mathrm{C} \text { CL-8 } 6.123 \\
(0.062-652)^{\wedge} \\
\mathrm{u}-\mathrm{C} \text { CL-10 } 3.611 \\
(0.0-34.2)^{\wedge} \\
\mathrm{u}-\mathrm{CCL}-20.445(0.0-19.2)^{\wedge} \\
\mathrm{u}-\mathrm{CCL}-50.73 \\
\text { In UTI group. } \\
\mathrm{u}-\mathrm{CXCL}-1, \mathrm{u}-\mathrm{CXCL}-5, \\
\mathrm{u}-\mathrm{CXCL}-8, \mathrm{u}-\mathrm{CVCL}-10, \\
\mathrm{u}-\mathrm{CCL}-2, \mathrm{u}-\mathrm{CCL}-5 \text { NO } \\
\text { detected in healthy group }\end{array}$ & $\begin{array}{l}\text { A complex CXC and CC } \\
\text { chemokine } \\
\text { response was detected in } \\
\text { patient urine, with a } \\
\text { significant } \\
\text { influence of the fimbrial } \\
\text { type }\end{array}$ \\
\hline
\end{tabular}


Table 6. Cont.

\begin{tabular}{|c|c|c|c|c|c|}
\hline $\begin{array}{c}\text { Study } \\
\text { Reference }\end{array}$ & Type of Study & Type of Patients & $\begin{array}{c}\text { Number of } \\
\text { Cases/Number of } \\
\text { Controls }\end{array}$ & Results & Finding \\
\hline $\begin{array}{l}\text { Ciszek M. et al. } \\
2006 \text { [26] }\end{array}$ & $\begin{array}{l}\text { Prospective } \\
\text { case-control study }\end{array}$ & $\begin{array}{l}\text { Kidney transplant } \\
\text { recipients with } \\
\text { bacteriuria }\end{array}$ & $\begin{array}{l}5 \text { UTIs / } 22 \text { ABU } / 25 \\
\text { controls }\end{array}$ & $\begin{array}{l}\mathrm{u}-\mathrm{CXCL}-8(\mathrm{pg} / \mathrm{mg} \\
\text { creatinine): } \\
33.492(2.97-129.749)^{\wedge} \text { in } \\
\text { ABU vs. } \\
2.97(2.97-44.164)^{\wedge} \text { in } \\
\text { Control, } p<0.01 \text {, } \\
146.801 \\
(24.646-2114.254)^{\wedge} \text { in } \\
\text { UTIs vs. } \\
2.97(2.97-44.164)^{\wedge} \text { in } \\
\text { Control, } p<0.001\end{array}$ & $\begin{array}{l}\text { A significant difference } \\
\text { was detected in } \\
\mathrm{u}-\mathrm{CXCL}-8 \text { levels between } \\
\text { ABU patients and } \\
\text { controls }(p<0.01) \text {, while } \\
\text { its levels increase } \\
\text { significantly in UTIs ( } p< \\
0.001)\end{array}$ \\
\hline $\begin{array}{l}\text { Olszyna D.P. et al. } \\
2001 \text { [27] }\end{array}$ & Case-control study & $\begin{array}{l}\text { Adults who } \\
\text { received a urinary } \\
\text { catheter }\end{array}$ & $\begin{array}{l}10 \text { UTI patients } / 20 \\
\text { no UTI patients }\end{array}$ & $\begin{array}{l}\text { CXCL-8 value not } \\
\text { reported }\end{array}$ & $\begin{array}{l}\text { CXCL- } 8 \text { is released in } \\
\text { the urine of postoperative } \\
\text { patients who had a } \\
\text { urinary catheter, and was } \\
\text { significantly higher in } \\
\text { patients who developed } \\
\text { UTIs }(p<0.01)\end{array}$ \\
\hline
\end{tabular}

ABU = asymptomatic bacteriuria; LUTS = lower urine tract symptoms; L-UTIs = lower urinary tract infections; U-UTIs $=$ upper urinary tract infection; $\mathrm{OAB}=$ over acting bladder; $\mathrm{NPV}=$ negative predictive value $\mathrm{PPV}=$ positive predictive value; $\mathrm{AUC}=$ area under curve; $\mathrm{OR}=$ odds ratio. $\left(^{\wedge}\right)$ variable represented as median (interquartile range), $\left(^{(}\right)$variable represented as median ( $\min -\max ),\left({ }^{\wedge}\right)$ variable represented as median/75th percentiles/90th percentiles.

Unfortunately, the studies are not consistent in the results, and their use in clinical practice cannot be recommended considering the little accuracy of urine Chks in UTI diagnosis. Nevertheless, the studies on CXCL-8, known as well as IL-8, showed a significant increase in the urine during UTIs [11,20,26,27,48] and good specificity [20,46]. Currently, CXCL-8 is the most promising chemokines in UTI diagnosis and should be studied in depth in future research, especially in combination with other biomarkers.

\subsection{Bone Morphogenetic Protein-2}

Bone morphogenetic protein-2 (BMP-2) is known for its important role in the development of bone and cartilage, but it seems to participate in the paracrine and autocrine action of organ regeneration [49]. Only one study investigated its role in UTI diagnosis and showed a significant increase in its serum levels in UTIs [50]. A cut-off point of 44 $\mathrm{pg} / \mathrm{mL}$ was shown to have accuracy as high as $86 \%$ in detecting UTIs. Unfortunately, we failed to identify other studies corroborating such findings, and the number of the cases and controls included in this study was too limited to suggest its use in clinical practice without further validation.

\subsection{Secretory Immunoglobulin A}

Secretory immunoglobulin A (S-IgA) is the major immunoglobulin isotype in external secretions of mucosal epithelia and the first line of local immunological defence. In UTIs, S-IgA was shown to inhibit the Escherichia coli adhesion to urinary epithelial cells [51].

Table 7 summarizes the characteristics and the main results of the two studies evaluating the role of s-IgA in the diagnosis of UTIs.

Although the results showed a significant increase in the biomarker during UTIs, its clinical use could not be suggested considering the quality of the studies and the limited number of cases. 
Table 7. Urine sIgA diagnostic value in UTIs; target population: adults.

\begin{tabular}{|c|c|c|c|c|c|}
\hline $\begin{array}{c}\text { Study } \\
\text { Reference }\end{array}$ & Type of Study & Type of Patients & $\begin{array}{c}\text { Number of } \\
\text { Cases/Number of } \\
\text { Controls }\end{array}$ & Results & Finding \\
\hline Deo S.S. et al. 2004 [51] & Case-control study & $\begin{array}{l}\text { Adults } \\
\text { and children }\end{array}$ & $\begin{array}{l}17 \text { adults with UTIs / } 10 \\
\text { adult as controls }\end{array}$ & $\begin{array}{l}\mathrm{sIgA}(\mathrm{ug} / \mathrm{mL}): \\
80( \pm 48)^{*} \text { in UTI } \\
5.2( \pm 0.73)^{*} \text { in controls, } \\
p<0.001\end{array}$ & $\begin{array}{l}\text { sIgA increased } \\
\text { significantly in adults } \\
\text { with UTIs, although in } \\
\text { children with UTIs, } \\
\text { sIgA increase was the } \\
\text { highest }\end{array}$ \\
\hline Floege J. et al. 1990 [52] & Case-control study & Adult women & $\begin{array}{l}\text { Group A: } 10 \text { recurrent } \\
\text { asymptomatic UTIs } \\
\text { Group B: } 8 \text { recurrent } \\
\text { asymptomatic UTIs } \\
\text { with urinary tract } \\
\text { abnormality } \\
\text { Group C: } 4 \text { recurrent } \\
\text { symptomatic UTIs } \\
\text { Group D: } 5 \text { selective IgA } \\
\text { deficiency } \\
68 \text { controls }\end{array}$ & sIgA value not reported & $\begin{array}{l}\text { sIgA increased } \\
\text { significantly in women } \\
\text { with UTIs regardless of } \\
\text { a recurrent UTI history. }\end{array}$ \\
\hline
\end{tabular}

$\left.{ }^{*}\right)$ variable represented as mean $( \pm$ standard deviation).

\subsection{Lactoferrin}

Lactoferrin (LF) is a multifunctional $80 \mathrm{KD}$ glycoprotein of the transferrin family. Its primary biological role is antimicrobial activity, interfering with bacteria growth by free iron sequester [53].

Table 8 summarizes the characteristics and the main results of the two studies evaluating the role LF in the diagnosis of UTIs.

Table 8. Urine lactoferrin diagnostic value in UTIs; target population: adults.

\begin{tabular}{|c|c|c|c|c|c|}
\hline $\begin{array}{c}\text { Study } \\
\text { Reference }\end{array}$ & Type of Study & Type of Patients & $\begin{array}{c}\text { Number of } \\
\text { Cases/Number of } \\
\text { Controls }\end{array}$ & Results & Finding \\
\hline $\begin{array}{l}\text { Gill K. et al. } \\
2021 \text { [35] }\end{array}$ & $\begin{array}{l}\text { Prospective, blind, } \\
\text { observational } \\
\text { cohort study }\end{array}$ & Adult women & $\begin{array}{l}24 \text { patients with } \mathrm{OAB} \\
\text { and } 22 \text { asymptomatic } \\
\text { control subjects }\end{array}$ & $\begin{array}{l}\text { The differences between } \\
\text { patients and controls in } \\
\text { urine lactoferrin }(\mathrm{F}= \\
228.5 p<0.001) \text {. } \\
\text { Lactoferrin levels were } \\
\text { predicted by LUTS score } \\
(p=0.003) \text {, urgency }(p= \\
0.011) \text { and pyuria count } \\
(p<0.001), \text { but not by } \\
\text { pain }(p=0.62) \text { and } \\
\text { bacteriuria }(p=0.79)\end{array}$ & $\begin{array}{l}\text { In OAB patients, } \\
\text { urinary lactoferrin was } \\
\text { associated } \\
\text { with pyuria and its } \\
\text { symptoms }\end{array}$ \\
\hline Arao S. et al. 1999 [53] & Case-control study & Adults & $\begin{array}{l}60 \text { UTIs } \\
28 \text { no UTIs }\end{array}$ & $\begin{array}{l}\text { LF }(\text { cut-off }>200 \\
\text { ng } / \mathrm{mL} \text { ): } \\
\text { Sensibility = 0.95, } \\
\text { Specificity = 0.929, PPV } \\
=0.96, \mathrm{NPV}=0.897, \\
\text { Accuracy }=0.94\end{array}$ & $\begin{array}{l}\text { LF measured by IC test } \\
\text { strip provided a useful } \\
\text { tool for the rapid and } \\
\text { simple detection of UTIs }\end{array}$ \\
\hline
\end{tabular}

LUTS = lower urinary tract symptoms; OAB = over active bladder; NPV = negative predictive value; $\mathrm{PPV}=$ positive predictive value.

Arao S. et al. (1999) suggested that LF levels $>200 \mathrm{ng} / \mathrm{mL}$ were associated with accuracy as high as $94 \%$ in the diagnosis of UTIs [53]. In the other report, Gill et al. showed the potential role of LF in the patients with overactive bladder syndrome to identify UTIs not diagnosed by standard urine cultures [42], but the findings of the study seem to be inclusive, and the conclusions are not fully supported by the data presented. Likely, more studies about the role of LF in UTI diagnosis are necessary to suggest its use in clinical practice.

\section{Conclusions}

Serum biomarkers showed their weakness in UTI diagnosis considering the limited positive predictive value. Although their use in clinical practice could be helpful to exclude upper UTIs and evaluate the severity of the infectious disease, few studies assess the 
reliability of serum markers in UTI diagnosis. Urine biomarkers are simple to collect and could be a precious help in uncertain UTI diagnoses. Unfortunately, their clinical use in this context cannot be suggested considering the current evidence (such as contradictory results, low number of patients, the different clinical settings and the different definitions of UTIs). Future studies in this field should focus on u-NGAL, u-IL-6, u-CXCL-8 and LF, which currently seems the most promising biomarker in UTI diagnosis.

Author Contributions: Conceptualization, F.K.M. and G.N., methodology, F.K.M. and G.N.; data curation, F.K.M. and G.N.; writing original draft preparation, F.K.M. and G.N., writing-review and editing, F.K.M. and G.N.; super-vision, G.N.; funding acquisition, not applicable. All authors have read and agreed to the published version of the manuscript.

Funding: This research received no external funding.

Institutional Review Board Statement: Ethical review and approval were waived for this study, due to the nature of the review.

Informed Consent Statement: Not applicable.

Data Availability Statement: Not applicable.

Acknowledgments: None.

Conflicts of Interest: The authors declare no conflict of interest.

\section{Appendix A}

Table A1. Research Strategy for Each Term.

\begin{tabular}{|c|c|c|c|}
\hline Term & Results & $\begin{array}{l}\text { Filters Applied: } \\
\text { English, Adult }\end{array}$ & Selected Items \\
\hline "Urinary" AND “Tract" AND “Infection" & 70,452 & Not applied & Not applied \\
\hline "Procalcitonin" & 7444 & Not applied & Not applied \\
\hline "Interleukin-6" & 95,463 & Not applied & Not applied \\
\hline "Neutrophil Gelatinase-Associated Lipocalin" & 5276 & Not applied & Not applied \\
\hline "Adenosine-5'-Triphosphate" & 120,102 & Not applied & Not applied \\
\hline "Proadrenomedullin" & 665 & Not applied & Not applied \\
\hline "beta2-Microglobilin" & 12,627 & Not applied & Not applied \\
\hline "Chemokine" & 121,862 & Not applied & Not applied \\
\hline "Bone morphogenetic protein-2" & 10,112 & Not applied & Not applied \\
\hline "Secretory" AND "Immunoglobulin A" & 6463 & Not applied & Not applied \\
\hline "Lactoferrin" & 9144 & Not applied & Not applied \\
\hline $\begin{array}{l}\text { "Urinary" AND “Tract" AND "Infection" AND } \\
\text { "Procalcitonin" }\end{array}$ & 221 & 57 & 7 \\
\hline $\begin{array}{l}\text { "Urinary" AND “Tract" AND "Infection" AND } \\
\text { "Interleukin-6" }\end{array}$ & 204 & 48 & 10 \\
\hline $\begin{array}{l}\text { "Urinary" AND “Tract" AND "Infection" AND } \\
\text { “Neutrophil Gelatinase-Associated Lipocalin" }\end{array}$ & 83 & 16 & 4 \\
\hline $\begin{array}{l}\text { "Urinary" AND "Tract" AND "Infection" AND } \\
\text { "Adenosine-5'-Triphosphate" }\end{array}$ & 44 & 6 & 2 \\
\hline $\begin{array}{l}\text { "Urinary" AND “Tract" AND “Infection" AND } \\
\text { "Proadrenomedullin" }\end{array}$ & 10 & 5 & 0 \\
\hline $\begin{array}{l}\text { "Urinary" AND “Tract" AND “Infection" AND } \\
\text { "beta2-Microglobilin" }\end{array}$ & 68 & 28 & 4 \\
\hline $\begin{array}{l}\text { "Urinary" AND "Tract" AND "Infection" AND } \\
\text { "Chemokine" }\end{array}$ & 229 & 53 & 8 \\
\hline $\begin{array}{l}\text { "Urinary" AND "Tract" AND "Infection" AND } \\
\text { "Bone morphogenetic protein-2" }\end{array}$ & 6 & 3 & 1 \\
\hline $\begin{array}{l}\text { "Urinary" AND “Tract" AND "Infection" AND } \\
\text { "Secretory Immunoglobulin A" }\end{array}$ & 68 & 20 & 2 \\
\hline $\begin{array}{l}\text { "Urinary" AND “Tract" AND “Infection" AND } \\
\text { "Lactoferrin" }\end{array}$ & 33 & 3 & 2 \\
\hline
\end{tabular}




\section{References}

1. Nicolle, L.E. Epidemiology of urinary tract infection. Infect. Med. 2001, 18, 153-162. [CrossRef]

2. Bonkat, G.; Bartoletti, R.; Bruyère, F.; Cai, T.; Geerlings, S.E.; Köves, B.; Schubert, S.; Wagenlehner, F. EAU Guidelines on Urological Infections; EAU Guidelines Office: Arnhem, The Netherlands, 2021.

3. Bent, S.; Nallamothu, B.K.; Simel, D.L.; Fihn, S.D.; Saint, S. Does this woman have an acute uncomplicated urinary tract infection? JAMA 2002, 287, 2701-2710. [CrossRef] [PubMed]

4. Bebell, L.M.; Muiru, A.N. Antibiotic use and emerging resistance: How can resource-limited countries turn the tide? Glob. Heart 2014, 9, 347-358. [CrossRef]

5. Foxman, B. Epidemiology of urinary tract infections: Incidence, morbidity, and economic costs. Am. J. Med. 2002, 113 (Suppl. 1A), 5S-13S. [CrossRef]

6. Sheng, Y.; Zheng, W.L.; Shi, Q.F.; Zhang, B.Y.; Yang, G.Y. Clinical characteristics and prognosis in patients with urosepsis from intensive care unit in Shanghai, China: A retrospective bi-centre study. BMC Anesthesiol. 2021, 21, 296-305. [CrossRef]

7. Schuetz, P.; Albrich, W.; Mueller, B. Procalcitonin for diagnosis of infection and guide to antibiotic decisions: Past, present, and future. BMC Med. 2011, 9, 107-120. [CrossRef]

8. Wacker, C.; Prkno, A.; Brunkhorst, F.M.; Schlattmann, P. Procalcitonin as a diagnostic marker for sepsis: A systematic review and meta-analysis. Lancet Infect. Dis. 2013, 13, 426-435. [CrossRef]

9. Boon, H.A.; Struyf, T.; Bullens, D.; Van den Bruel, A.; Verbakel, J.Y. Diagnostic value of biomarkers for paediatric urinary tract infections in primary care: Systematic review and meta-analysis. BMC Fam. Pract. 2021, 22, 193. [CrossRef]

10. Shaikh, K.J.; Osio, V.A.; Leeflang, M.M.; Shaikh, N. Procalcitonin, C-reactive protein, and erythrocyte sedimentation rate for the diagnosis of acute pyelonephritis in children. Cochrane Database Syst. Rev. 2020, 9, CD009185.

11. Rodhe, N.; Löfgren, S.; Strindhall, J.; Matussek, A.; Mölstad, S. Cytokines in urine in elderly subjects with acute cystitis and asymptomatic bacteriuria. Scand. J. Prim. Health Care 2009, 27, 74-79. [CrossRef]

12. Li, Y.M.; Xu, J.H.; Zhao, Y.X. Predictors of urinary tract infection in acute stroke patients: A cohort study. Medicine 2020, 99 , e20952. [CrossRef] [PubMed]

13. Levine, A.R.; Tran, M.; Shepherd, J.; Naut, E. Utility of initial procalcitonin values to predict urinary tract infection. Am. J. Emerg. Med. 2018, 36, 1993-1997. [CrossRef] [PubMed]

14. Iftimie, S.; García-Heredia, A.; Pujol, I.; Ballester, F.; Fort-Gallifa, I.; Simó, J.M.; Joven, J.; Camps, J.; Castro, A. Preliminary study on serum paraoxonase-1 status and chemokine (C-C motif) ligand 2 in hospitalized elderly patients with catheter-associated asymptomatic bacteriuria. Eur. J. Clin. Microbiol. Infect. Dis. 2016, 35, 1417-1424. [CrossRef] [PubMed]

15. Masajtis-Zagajewska, A.; Kurnatowska, I.; Wajdlich, M.; Nowicki, M. Utility of copeptin and standard inflammatory markers in the diagnostics of upper and lower urinary tract infections. BMC Urol. 2015, 15, 1-6. [CrossRef] [PubMed]

16. Van Nieuwkoop, C.; Bonten, T.N.; va not Wout, J.W.; Kuijper, E.J.; Groeneveld, G.H.; Becker, M.J.; Koster, T.; Wattel-Louis, G.H.; Delfos, N.M.; Ablij, H.C.; et al. Procalcitonin reflects bacteremia and bacterial load in urosepsis syndrome: A prospective observational study. Crit. Care 2010, 14, R206. [CrossRef] [PubMed]

17. Kishimoto, T. IL-6: From its discovery to clinical applications. Int. Immunol. 2010, 22, 347-352. [CrossRef]

18. Kishimoto, T.; Ishizaka, K. Regulation of antibody response in vitro. Suppression of secondary response by anti-immunoglobulin heavy chains. J. Immunol. 1971, 107, 1567.

19. Gill, K.; Horsley, H.; Swamy, S.; Khasriya, R.; Malone-Lee, J. A prospective observational study of urinary cytokines and inflammatory response in patients with Overactive Bladder Syndrome. BMC Urol. 2021, 21, 39. [CrossRef]

20. Gadalla, A.A.H.; Friberg, I.M.; Kift-Morgan, A.; Zhang, J.; Eberl, M.; Topley, N.; Weeks, I.; Cuff, S.; Wootton, M.; Gal, M.; et al. Identification of clinical and urine biomarkers for uncomplicated urinary tract infection using machine learning algorithms. Sci. Rep. 2019, 9, 1-11. [CrossRef]

21. Kjölvmark, C.; Tschernij, E.; Öberg, J.; Påhlman, L.I.; Linder, A.; Åkesson, P. Distinguishing asymptomatic bacteriuria from urinary tract infection in the elderly-The use of urine levels of heparin-binding protein and interleukin-6. Diagn. Microbiol. Infect. Dis. 2016, 85, 243-248. [CrossRef]

22. Sundén, F.; Wullt, B. Predictive value of urinary interleukin-6 for symptomatic urinary tract infections in a nursing home population. Int. J. Urol. 2016, 23, 168-174. [CrossRef]

23. Van der Starre, W.E.; Zunder, S.M.; Vollaard, A.M.; van Nieuwkoop, C.; Stalenhoef, J.E.; Delfos, N.M.; Va not Wout, J.W.; Spelt, I.C.; Blom, J.W.; Leyten, E.M.; et al. Prognostic value of pro-adrenomedullin, procalcitonin and C-reactive protein in predicting outcome of febrile urinary tract infection. Clin. Microbiol. Infect. 2014, 20, 1048-1054. [CrossRef] [PubMed]

24. Sundvall, P.D.; Elm, M.; Ulleryd, P.; Mölstad, S.; Rodhe, N.; Jonsson, L.; Andersson, B.; Hahn-Zoric, M.; Gunnarsson, R. Interleukin- 6 concentrations in the urine and dipstick analyses were related to bacteriuria but not symptoms in the elderly: A cross sectional study of 421 nursing home residents. BMC Geriatr. 2014, 14, 88. [CrossRef] [PubMed]

25. Grönberg-Hernández, J.; Sundén, F.; Connolly, J.; Svanborg, C.; Wullt, B. Genetic control of the variable innate immune response to asymptomatic bacteriuria. PLOS ONE 2011, 6, e28289.

26. Ciszek, M.; Paczek, L.; Bartłomiejczyk, I.; Mucha, K. Urine cytokines profile in renal transplant patients with asymptomatic bacteriuria. Transplantation 2006, 81, 1653-1657. [CrossRef] [PubMed]

27. Olszyna, D.P.; Vermeulen, H.; Baan, A.H.; Speelman, P.; van Deventer, S.J.; Gouma, D.J.; van der Poll, T. Urine interleukin-8 is a marker for urinary tract infection in postoperative patients. Infection 2001, 29, 274-277. [CrossRef] [PubMed] 
28. Nicolle, L.E.; Brunka, J.; Orr, P.; Wilkins, J.; Harding, G.K. Urinary immunoreactive interleukin-1 alpha and interleukin-6 in bacteriuric institutionalized elderly subjects. J Urol. 1993, 149, 1049-1053. [CrossRef]

29. Ko, Y.C.; Mukaida, N.; Ishiyama, S.; Tokue, A.; Kawai, T.; Matsushima, K.; Kasahara, T. Elevated interleukin-8 levels in the urine of patients with urinary tract infections. Infect Immun. 1993, 61, 1307-1314. [CrossRef]

30. Schmidt-Ott, K.M.; Mori, K.; Li, J.Y.; Kalandadze, A.; Cohen, D.J.; Devarajan, P.; Barasch, J. Dual action of neutrophil gelatinaseassociated lipocalin. J. Am. Soc. Nephrol. 2007, 18, 407-413. [CrossRef]

31. Price, J.R.; Guran, L.; Lim, J.Y.; Meglim, C.J.; Clark, A.L.; Edwards, S.R.; Denman, M.A.; Gregory, W.T. Neutrophil GelatinaseAssociated Lipocalin Biomarker and Urinary Tract Infections: A Diagnostic Case-Control Study (NUTI Study). Female Pelvic Med. Reconstr. Surg. 2017, 23, 101-107. [CrossRef]

32. Urbschat, A.; Obermüller, N.; Paulus, P.; Reissig, M.; Hadji, P.; Hofmann, R.; Geiger, H.; Gauer, S. Upper and lower urinary tract infections can be detected early but not be discriminated by urinary NGAL in adults. Int. Urol. Nephrol. 2014, 46, 2243-2249. [CrossRef] [PubMed]

33. Decavele, A.S.; Dhondt, L.; De Buyzere, M.L.; Delanghe, J.R. Increased urinary neutrophil gelatinase associated lipocalin in urinary tract infections and leukocyturia. Clin. Chem. Lab. Med. 2011, 49, 999-1003. [CrossRef] [PubMed]

34. Van der Weyden, L.; Conigrave, A.D.; Morris, M.B. Signal transduction and white cell maturation via extracellular ATP and the P2Y11 receptor. Immunol. Cell Biol. 2000, 78, 369-374. [CrossRef] [PubMed]

35. Gill, K.; Horsley, H.; Kupelian, A.S.; Baio, G.; De Iorio, M.; Sathiananamoorthy, S.; Khasriya, R.; Rohn, J.L.; Wildman, S.S.; Malone-Lee, J. Urinary ATP as an indicator of infection and inflammation of the urinary tract in patients with lower urinary tract symptoms. BMC Urol. 2015, 15, 7. [CrossRef] [PubMed]

36. Lundin, A.; Hallander, H.; Kallner, A.; Lundin, U.K.; Osterberg, E. Bacteriuria testing by the ATP method as an integral part in the diagnosis and therapy of urinary tract infection (UTI). J. Biolumin. Chemilumin. 1989, 4, 381-389. [CrossRef] [PubMed]

37. Hallander, H.O.; Kallner, A.; Lundin, A.; Osterberg, E. Evaluation of rapid methods for the detection of bacteriuria (screening) in primary health care. Acta Pathol. Microbiol. Scand. Ser. B Microbiol. 1986, 94, 39-49. [CrossRef]

38. Li, P.; Wang, C.; Pang, S. The diagnostic accuracy of mid-regional pro-adrenomedullin for sepsis: A systematic review and meta-analysis. Minerva Anestesiol. 2021, 87, 1117-1127. [CrossRef]

39. Drozdov, D.; Thomer, A.; Meili, M.; Schwarz, S.; Kouegbe, R.B.; Regez, K.; Guglielmetti, M.; Schild, U.; Conca, A.; Schäfer, P.; et al. Procalcitonin, pyuria and proadrenomedullin in the management of urinary tract infections-'triple $p$ in uti': Study protocol for a randomized controlled trial. Trials 2013, 14,1-13. [CrossRef]

40. Stalenhoef, J.E.; van Nieuwkoop, C.; Wilson, D.C.; van der Starre, W.E.; van der Reijden, T.J.K.; Delfos, N.M.; Leyten, E.M.S.; Koster, T.; Ablij, H.C.; van 't Wout, J.J.W.; et al. Procalcitonin, mid-regional proadrenomedullin and C-reactive protein in predicting treatment outcome in community-acquired febrile urinary tract infection. BMC Infect Dis. 2019, 19, 161. [CrossRef]

41. Sandberg, T.; Bergmark, J.; Hultberg, B.; Jagenburg, R.; Trollfors, B. Diagnostic potential of urinary enzymes and beta 2microglobulin in acute urinary tract infection. Acta Med. Scand. 1986, 219, 489-495. [CrossRef]

42. Schardijn, G.; Statius van Eps, L.W.; Pauw, W.; Hoefnagel, C.; Nooyen, W.J. Comparison of reliability of tests to distinguish upper from lower urinary tract infection. Br. Med. J. (Clin. Res Ed.). 1984, 289, 284-287. [CrossRef] [PubMed]

43. Mengoli, C.; Lechi, A.; Arosio, E.; Rizzotti, P.; Lechi, C.; Corgnati, A.; Micciolo, R.; Pancera, P. Contribution of four markers of tubular proteinuria in detecting upper urinary tract infections. A multivariate analysis. Nephron 1982, 32, 234-238. [CrossRef] [PubMed]

44. Schardijn, G.; Statius van Eps, L.W.; Swaak, A.J.; Kager, J.C.; Persijn, J.P. Urinary beta 2 microglobulin in upper and lower urinary-tract infections. Lancet 1979, 1, 805-807. [CrossRef]

45. Tyagi, P.; Tyagi, V.; Qu, X.; Chuang, Y.C.; Kuo, H.C.; Chancellor, M. Elevated CXC chemokines in urine noninvasively discriminate OAB from UTI. Am. J. Physiol. Ren. Physiol. 2016, 311, F548-F554. [CrossRef] [PubMed]

46. Hawn, T.R.; Scholes, D.; Wang, H.; Li, S.S.; Stapleton, A.E.; Janer, M.; Aderem, A.; Stamm, W.E.; Zhao, L.P.; Hooton, T.M. Genetic variation of the human urinary tract innate immune response and asymptomatic bacteriuria in women. PLoS ONE 2009, 4, e8300. [CrossRef] [PubMed]

47. Godaly, G.; Otto, G.; Burdick, M.D.; Strieter, R.M.; Svanborg, C. Fimbrial lectins influence the chemokine repertoire in the urinary tract mucosa. Kidney Int. 2007, 71, 778-786. [CrossRef]

48. Grgurevic, L.; Macek, B.; Healy, D.R.; Brault, A.L.; Erjavec, I.; Cipcic, A.; Grgurevic, I.; Rogic, D.; Galesic, K.; Brkljacic, J.; et al. Circulating bone morphogenetic protein 1-3 isoform increases renal fibrosis. J. Am. Soc. Nephrol. 2011, 22, 681-692. [CrossRef]

49. Salama, R.H.; Alghasham, A.; Mostafa, M.S.; El-Moniem, A.E. Bone morphogenetic protein-2 will be a novel biochemical marker in urinary tract infec-tions and stone formation. Clin. Biochem. 2012, 45, 766-769. [CrossRef]

50. Deo, S.S.; Vaidya, A.K. Elevated levels of secretory immunoglobulin A (sIgA) in urinary tract infections. Indian J. Pediatr. 2004, 71, 37-40. [CrossRef]

51. Floege, J.; Böddeker, M.; Stolte, H.; Koch, K.M. Urinary IgA, secretory IgA and secretory component in women with recurrent urinary tract infections. Nephron 1990, 56, 50-55. [CrossRef]

52. Wang, B.; Timilsena, Y.P.; Blanch, E.; Adhikari, B. Lactoferrin: Structure, function, denaturation and digestion. Crit. Rev. Food. Sci. Nutr. 2019, 59, 580-596. [CrossRef] [PubMed]

53. Arao, S.; Matsuura, S.; Nonomura, M.; Miki, K.; Kabasawa, K.; Nakanishi, H. Measurement of urinary lactoferrin as a marker of urinary tract infection. J. Clin. Microbiol. 1999, 37, 553-557. [CrossRef] [PubMed] 